Reviu Akuntansi dan Bisnis Indonesia, Vol. 3 No. 1, Hlm: 85-101, Juli 2019

Website: http://journal.umy.ac.id/index.php/rab

\title{
Publikasi Laporan Keuangan Pemerintah Daerah di Internet dan Faktor yang Memengaruhinya
}

Triana Saraswati; Laeli Budiarti * Yudha Aryo Sudibyo

Program Studi Akuntansi Universitas Jenderal Soedirman

\section{N F O A R T I K E L}

Kata Kunci:

Publikasi, Laporan

Keuangan, Pemerintah

Daerah, Internet

Jenis Artikel:

Penelitian Empiris

\section{${ }^{*}$ Correspondence:}

laeli_budiarti@yahoo.co.id

\author{
A B S T R A K
}

Penelitian ini bertujuan untuk menguji analisis faktor-faktor yang memengaruhi publikasi laporan keuangan pemerintah daerah di internet. Penelitian ini adalah penelitian kuantitatif dengan menggunakan data sekunder yang berasal dari laporan keuangan pemerintah daerah. Populasi dalam penelitian ini adalah113 pemerintah daerah kabupaten di Pulau Jawa kecuali Provinsi DKI Jakarta. Purposive sampling digunakan untuk mengumpulkan data sampel. Kami menggunakan analisis regresi logistik untuk menguji empat hipotesis. Variabel bebas penelitian ini adalah opini audit, pengeluaran daerah, pendapatan per kapita, dan keberadaan LPSE, sedangkan variabel dependennya adalah publikasi laporan keuangan di internet. Hasil penelitian ini menunjukkan bahwa pengeluaran daerah dan pendapatan per kapita mempengaruhi publikasi laporan keuangan pemerintah daerah di internet. Semakin tinggi realisasi pengeluaran daerah dan pendapatan per kapita, semakin tinggi kemungkinan publikasi laporan keuangan di internet. Meski demikian kami tidak berhasil menemukan bukti empiris yang menunjukkan bahwa opini audit dan keberadaan situs web LPSE berpengaruh pada publikasi laporan keuangan pemerintah daerah di internet. Pendapat audit dan keberadaan situs web LPSE tidak mendorong pemerintah daerah untuk menerbitkan laporan keuangan di internet.

(C) 2019 RAB. Published by Universitas Muhammadiyah Yogyakarta

\section{PENDAHULUAN}

Otonomi daerah merupakan kewenangan yang diberikan kepada pemerintah daerah provinsi, kota, dan kabupaten untuk menyusun, mengatur, dan mengurus sendiri urusan pemerintahannya tanpa ada campur tangan serta bantuan dari pemerintah pusat.Adanya pelimpahan wewenang dari pemerintah pusat kepada pemerintah daerah berimplikasi terhadap akuntabilitas dan transparansi pengelolaan keuangan daerah.Salah satu bentuk transparansi dan akuntabilitas pemerintah daerah yaitu dengan menyusun laporan keuangan daerah. Laporan keuangan tersebut kemudian diaudit oleh BPK dan disampaikan kepada DPRD.

Transparansi dan akuntabilitas dapat berjalan apabila informasi yang disajikan relevan dan dapat diakses oleh semua pihak. Dengan demikian agar laporan keuangan dapat diakses oleh semua pihak, pemerintah daerah seharusnya memublikasikan laporan keuangan melalui media-media yang dapat dijangkau oleh masyarakat, seperti media internet, surat kabar dan majalah. Perkembangan teknologi yang semakin canggih memungkinkan pemerintah untuk dapat menyampaikan laporan keuangan secara terbuka dan dapat diakses oleh semua pihak. Salah satu teknologi yang sedang berkembang pesat yang dapat dimanfaatkan oleh pemerintah adalah internet. 
Khan dan Ismail (2012) mengatakan bahwa internet menjadi salah satu sumber informasi yang paling sering digunakan oleh masyarakat, pemerintah, dan perusahaan.

Pina dan Royo (2010) menyatakan untuk meningkatkan transparansi dan akuntabilitas pengelolaan keuangan, pemerintah dapat menggunakan media internet untuk menyajikan dan melakukan diseminasi laporan keuangannya. Penyampaian laporan keuangan di internet merupakan cara yang mudah dan murah bagi pemerintah daerah untuk mempertangungjawabkan pengelolaan keuangan daerah kepada masyarakat. Selain itu, publikasi laporan keuangan di internet juga akan memberikan dampak yang positif bagi pemerintah daerah yaitu meningkatnya kepercayaan investor dan masyarakat.

Namun, media internet belum dimanfaatkan secara maksimal oleh pemerintah daerah untuk menyampaikan laporan keuangan. Tidak semua pemerintah daerah secara sukarela mengambil manfaat dari penggunaan internet sebagai media untuk menyampaikan laporan keuangan kepada masyarakat (Wau dan Ratmono, 2015). Dari semua Provinsi di Pulau Jawa kecuali Provinsi DKI Jakarta hanya $51 \mathrm{Kab} /$ Kota yang memublikasikan laporan keuangan pemerintah daerah tahun 2014 dari jumlah keseluruhan $113 \mathrm{Kab} /$ Kota.

Berdasarkan tabel 1 dapat diketahui bahwa jumlah pemerintah daerah Kab/Kota di Pulau Jawa yang mau memublikasikan laporan keuangan di website $<50 \%$ dari jumlah keseluruhan pemerintah daerah Kab/Kota di Pulau Jawa. Hal tersebut menunjukan bahwa pemerintah daerah masih enggan untuk memublikasikan laporan keuangan di website daerahnya. Hasil penelitian Forum Indonesia untuk Transparansi Anggaran (FITRA) tahun 2013 menyatakan bahwa pemerintah Kota/Kabupaten dinilai pelit dalam menginformasikan anggarannya.

Penelitian dari Rahim dan Dwi (2016) menunjukan bahwa opini audit memiliki hubungan positif terhadap pengungkapan informasi keuangan pada website. Pemerintah daerah yang mendapatkan opini WTP akan cenderung melakukan publikasi laporan keuangan di internet. Akan tetapi, sebaliknya jika semakin tinggi penyimpangan dalam laporan keuangan pemerintah daerah akan mendorong pemerintah daerah untuk menutupi informasi keuangan, sehingga publikasi laporan keuangan menjadi rendah (Handayani, 2010).

Pemerintah daerah juga akan menutupi informasi keuangan apabila realisasi belanja daerah tidak maksimal. Belanja daerah adalah pengeluaran pemerintah daerah pada satu periode anggaran yang digunakan untuk melaksanakan wewenang dan tanggung jawab kepada pemerintah pusat dan masyarakat. Belanja daerah yang tinggi akan mendorong pemerintah daerah untuk memublikasikan laporan keuangannya di internet. Penelitian dari Pratama dkk. (2015) dan Hendriyani dan Afrizal (2015) menunjukan bahwa belanja daerah memiliki pengaruh positif terhadap publikasi konten informasi pelaporan keuangan pemerintah daerah pada website. Hal ini untuk menunjukan seberapa besar dana yang sudah terserap yang dianggarkan melalui APBD untuk memberikan pelayanan kepada masyarakat.

Tabel 1 Publikasi LKPD Kab/Kota tahun 2014

\begin{tabular}{ccccccc}
\hline Nama Provinsi & \multicolumn{2}{c}{$\begin{array}{c}\text { Jumlah Kab/Kota } \\
\text { Memublikasikan } \\
\text { LKPD }\end{array}$} & \multicolumn{2}{c}{$\begin{array}{c}\text { Jumlah Kab/Kota } \\
\text { Tidak Memublikasikan }\end{array}$} & Jumlah Kab/Kota \\
& Jumlah & Prosentase & Jumlah & Prosentase & Jumlah & Prosentase \\
\hline Jawa Barat & 16 & $31 \%$ & 11 & $18 \%$ & 27 & $24 \%$ \\
Jawa Tengah & 11 & $22 \%$ & 24 & $39 \%$ & 35 & $31 \%$ \\
DIY & 4 & $8 \%$ & 1 & $2 \%$ & 5 & $4 \%$ \\
Jawa Timur & 15 & $29 \%$ & 23 & $37 \%$ & 38 & $34 \%$ \\
Banten & 5 & $10 \%$ & 3 & $5 \%$ & 8 & $7 \%$ \\
Total & 51 & $100 \%$ & 62 & $100 \%$ & 113 & $100 \%$ \\
\hline
\end{tabular}

Sumber: Website Pemerintah Daerah, 2014

Indikator kualitas pelayanan dapat dilihat dari kesejahteraan masyarakat. Styles dan Tennyson (2007) menunjukan bahwa semakin tinggi pendapatan per kapita daerah semakin tinggi pula political monitoring oleh masyarakat dan semakin tinggi permintaan informasi yang disediakan 
pada situs untuk mengukur kinerja pemerintah daerahnya. Menurut penelitian Hudoyo dan Amir (2014), pendapatan per kapita daerah berpengaruh terhadap pelaporan keuangan di internet oleh pemerintah daerah. Semakin tinggi pendapatan masyarakat dalam suatu daerah maka semakin tinggi pula kemampuan dalam mengadopsi teknologi untuk mendapatkan informasi.

Pengungkapan informasi daerah dalam website merupakan salah satu cara untuk mengurangi agency problem antara pemerintah dan masyarakat. Adanya hubungan antara pemerintah sebagai agent dan masyarakat sebagai principal merupakan salah satu pentingnya akuntabilitas dan transparansi. Untuk meningkatkan akuntabilitas dan transparansi, khususnya dalam pengadaan barang/jasa, pemerintah membuat suatu sistem yang disebut Layanan Pengadaan Secara Elektronik (LPSE). Penelitian dengan menggunakan variabel keberadaan situs LPSE terhadap publikasi laporan keuangan pemerintah daerah di internet belum pernah dilakukan sebelumnya. Adanya sistem LPSE diharapkan juga akan mendorong pemerintah daerah untuk lebih meningkatkan transparansi dan akuntabilitas laporan keuangan dengan cara memublikasikan laporan keuangan pemerintah daerah di internet.

Penelitian mengenai faktor-faktor yang memengaruhi publikasi laporan keuangan pemerintah daerah di internet (website) sudah banyak dilakukan. Penelitian ini merupakan penelitian replikasi dari penelitian Trisnawati dan Komarudin (2014). Perbedaan penelitian ini dengan penelitian sebelumnya adalah menambah variabel independen berupa variabel belanja daerah, pendapatan per kapita, dan keberadaan situs LPSE. Selain itu, penelitian ini juga menguji kembali variabel independen yang digunakan dalam penelitian Trisnawati dan Komarudin (2014) yaitu variabel opini audit. Berdasarkan latarbelakang tersebut mengundang pertanyaan apakah ada faktor yang memengaruhi publikasi laporan keuangan di internet oleh pemerintah daerah.

\section{TINJAUAN LITERATUR DAN PERUMUSAN HIPOTESIS}

Teori Sinyal

Teori Sinyal pertama kali dikemukakan oleh Michael Spence pada tahun 1973, yang menyatakan bahwa dengan memberikan suatu sinyal, pihak pengirim (pemilik informasi) berusaha untuk memberikan informasi yang relevan yang dapat dimanfaatkan oleh pihak penerima. Menurut Jama'an (2008) teori sinyal mengemukakan tentang bagaimana seharusnya sebuah perusahaan memberikan sinyal kepada pengguna laporan keuangan.Sinyal ini berupa informasi mengenai apa yang sudah dilakukan oleh manajemen untuk merealisasikan kenginginan pemilik. Prinsip dari teori sinyal adalah bahwa setiap tindakan mengandung informasi.

Dalam konteks pemerintahan, teori sinyal menjelaskan bahwa pemerintah sebagai agent yang diberikan amanah oleh masyarakat sebagai principal berkeinginan untuk menunjukan sinyal yang baik kepada masyarakat. Hal positif dalam teori sinyal yaitu apabila pemerintah memberikan informasi yang baik, maka dapat membedakan mereka dengan pemerintah lain yang tidak memiliki informasi yang baik dengan memberikan informasi tentang kondisi mereka (Wolk and Tearney, 1997) dalam Wulandari (2016). Menurut Widarjo (2011) dalam Wulandari (2016), dengan sinyal positif dari pemerintah, diharapkan bisa mendapatkan respon positif dari masyarakat karena hal tersebut dapat memberikan penilaian yang lebih dari masyarakat kepada pemerintah.

\section{Perumusan Hipotesis}

Pengaruh Opini Audit terhadap Publikasi Laporan Keuangan Pemerintah Daerah di Internet

Liestiani (2008) dalam Rahim dan Dwi (2016) melakukan penelitian terhadap tingkat pengungkapan pada LKPD dengan memasukkan salah satu faktor jumlah temuan audit pada LKPD dan diperoleh hubungan positif terhadap tingkat pengungkapan informasi keuangan pada LKPD karena semakin banyak jumlah temuan yang diperoleh BPK, maka akan semakin besar jumlah informasi yang akan diminta BPK dalam laporan keuangannya. Hasil penelitian dari Rahim 
dan Dwi (2016) menunjukan bahwa opini audit memiliki hubungan positif terhadap pengungkapan informasi keuangan pada website.Sejalan dengan penelitian Rahim dan Dwi (2016). Hasil penelitian Andriani (2012) menunjukkan bahwa ada hubungan positif antara opini audit dengan tingkat pengungkapan. Hal tersebut disimpulkan bahwa jika temuan audit BPK akan berdampak pada kepercayaan pemerintah dalam melakukan pengungkapan luas untuk menghindari persepsi negatif dari publik.

Berdasarkan penelitian-penelitian yang telah dijabarkan di atas serta telaah literatur penelitian sebelumnya, penulis menurunkan kerangka berpikir bahwa pemerintah daerah yang mendapatkan opini audit baik dari BPK akan cenderung untuk memublikasikan laporan keuangan di websitenya. Hal ini untuk menunjukan kepada masyarakat bahwa kinerja keuangan pemerintah baik sehingga masyarakat akan mendukung jalannya pemerintahan. Akan tetapi sebaliknya jika semakin tinggi penyimpangan dalam laporan keuangan pemerintah daerah akan mendorong pemerintah daerah untuk menutupi informasi keuangan, sehingga pengungkapan laporan keuangan menjadi rendah (Handayani, 2010). Berdasarkan uraian di atas, hipotesis pertama penelitian ini adalah:

\section{$\boldsymbol{H}_{I} \quad$ : Opini audit WTP mendorong pemerintah daerah untuk publikasi laporan keuangan di internet}

Pengaruh Belanja Daerah terhadap Publikasi Laporan Keuangan Pemerintah Daerah di Internet

Penelitian dari Pratama dkk. (2015) dan Hendriyani dan Afrizal (2015) menunjukan bahwa belanja daerah memiliki pengaruh positif terhadap publikasi konten informasi pelaporan keuangan pemerintah daerah pada website. Hasil analisis ini menunjukan bahwa nilai belanja daerah sangat menentukan pelaporan keuangan pemerintah daerah. Hal ini menunjukkan bahwa pemerintah daerah yang memiliki belanja yang tinggi secara otomatis akan melakukan pengungkapan konten informasi pelaporan keuangan pemerintah daerah. Sejalan dengan hasil penelitian Pratama dkk. (2015) dan Hendriyani dan Afrizal (2015). Hasil penelitian Rora (2010) dan Christina (2013) menunjukan bahwa belanja daerah berpengaruh terhadap pelaporan keuangan pemerintah daerah pada website. Semakin tinggi pelaksanaan program yang dilakukan oleh pemerintah, maka keinginan pemerintah daerah mengungkapkan informasi keuangan pada websitenya akan meningkat.

Berdasarkan penelitian-penelitian yang telah dijabarkan di atas serta telaah literatur penelitian sebelumnya, penulis menurunkan kerangka berpikir bahwa belanja daerah yang tinggi akan mendorong pemerintah daerah untuk memublikasikan laporan keuangannya di internet. Hal ini untuk menunjukan seberapa besar dana yang sudah terserap yang dianggarkan melalui APBD untuk memberikan pelayanan kepada masyarakat. Sehingga semakin besar pelayanan yang diberikan oleh pemerintah daerah kepada masyarakat, semakin besar pula keinginan pemerintah daerah untuk memublikasikan laporan keuangannya di internet. Oleh karena itu, hipotesis kedua penelitian ini adalah:

\section{$\boldsymbol{H}_{2} \quad$ :Realisasi belanja daerah yang tinggi mendorong pemerintah daerah untukpublikasi laporan keuangan di internet}

Pengaruh Pendapatan per Kapita terhadap Publikasi Laporan Keuangan Pemerintah Daerah di Internet

Menurut penelitian Hudoyo dan Amir (2014), pendapatan per kapita daerah berpengaruh terhadap pelaporan keuangan di internet oleh pemerintah daerah. Perekonomian masyarakat setempat akan memengaruhi teknologi yang di adaptasi oleh masyarakat tersebut. Sehingga, pengungkapan laporan keuangan di internet pun bisa dipengaruhi oleh pendapatan perkapita daerah tersebut. Sejalan dengan hasil penelitian Hudoyo dan Amir (2014). Hasil penelitian 
Hasanah (2015) menunjukan bahwa pendapatan perkapita berpengaruh positif dan signifikan terhadap publikasi informasi keuangan pemerintah di website. Hal ini dikarenakan pemerintah daerah yang memiliki pendapaptan per kapita tinggi mendapat tekanan untuk melakukan pengungkapan informasi keuangan karena semakin tinggi tingkat kebutuhan dan pendidikan masyarakat yang menuntut transparansi keuangan. Sehingga pendapatan per kapita yang tinggi mendorong pemerintah daerah untuk melakukan publikasi laporan keuangan di internet.

Berdasarkan penelitian-penelitian yang telah dijabarkan di atas serta telaah literatur penelitian sebelumnya, penulis menurunkan kerangka berpikir bahwa semakin besar pendapatan per kapita pada suatu wilayah, maka pemerintah daerah cenderung akan memublikasikan laporan keuangannya di internet. Jika tingkat kesejahteraan disuatu daerah baik, maka pola pikir masyarakat cenderung lebih maju dan semakin tinggi pula political monitoring yang dilakukan oleh masyarakat. Sehingga semakin besar pendapat per kapita yang diperoleh suatu wilayah akan mendorong pemerintah daerah untuk memublikasikan laporan keuangannya. Oleh karena itu, hipotesis ketiga penelitian ini adalah:

\section{$\boldsymbol{H}_{3} \quad$ : Pendapatan per kapita yang tinggi mendorong pemerintah daerah untuk publikasi laporan} keuangan di internet

Pengaruh Keberadaan Situs LPSE terhadap Publikasi Laporan Keuangan Pemerintah Daerah di Internet

Salah satu upaya untuk meningkatkan akuntabilitas dan transparansi, khususnya pengadaan barang dan jasa dalam pemerintahan, pemerintah membuat sistem Layanan Pengadaan Secara Elektronik (LPSE). LPSE adalah unit kerja yang dibentuk di seluruh Kementerian/Lembaga/Satuan Kerja Perangkat Daerah/lnstitusi Lainnya $(\mathrm{K} / \mathrm{L} / \mathrm{D} / \mathrm{I})$ untuk menyelenggarakan sistem pelayanan pengadaan barang/jasa secara elektronik serta memfasilitasi ULP/Pejabat Pengadaan dalam melaksanakan pengadaan barang/jasa secara elektronik (LKPP, 2011).Proses pengadaan barang/jasa pemerintah secara elektronik juga akan lebih meningkatkan dan menjamin terjadinya efisiensi, efektifitas, dan akuntabilitas dalam menggunakan uang negara.

Menurut Wibawa (2014) melalui e-procurement, transparansi, akuntabilitas, dan partisipasi masyarakat dapat diperoleh melalui akses yang lebih baik ke informasi (Wibawa, 2014). Oleh karena itu, penulis mempunyai kerangka pikiran bahwa dengan keberadaan sistem LPSE akan mendorong pemerintah daerah untuk memublikasikan laporan keuangan di internet. Alasannya karena pengadaan barang/jasa yang dilakukan secara elektronik melalui website, sehingga meningkatkan transaparansi dalam pengelolaan keuangan negara yang nantinya juga akan mendorong pemerintah daerah untuk meningkatan transparansi dan akuntabilitas laporan keuangan dengan cara memublikasikan laporan keuangan di internet. Oleh karena itu, hipotesis kelima penelitian ini adalah:

$H_{4} \quad$ : Keberadaan Situs LPSE pemerintah daerah mendorongpemerintah daerah untuk publikasi laporan keuangan di internet

\section{METODE PENELITIAN}

Jenis Penelitian

Jenis penelitian yang digunakan dalam penelitian ini adalah penelitian eksplanatory dengan pendekatan kuantitatif. Penelitian kuantitatif adalah penelitian ilmiah yang dilaksanakan secara sistematis, berfokus pada pengukuran, bertujuan untuk menguji fenomena serta hubungannya, dan didasarkan pada teori-teori yang berkaitan dengan fenomena tersebut (Jogiyanto, 2013). Penelitian 
ini bertujuan untuk menguji pengaruh opini audit, belanja daerah, pendapatan per kapita, dan keberadaan situs LPSE terhadap publikasi laporan keungan pemerintah daerah di internet.

\section{Jenis Data, Sumber Data, dan Metode Pengumpulan Data}

Data yang digunakan dalam penelitian ini adalah data sekunder. Data sekunder merupakan sumber data penelitian yang diperoleh secara tidak langsung, melalui media perantara. Data sekunder tersebut berupa laporan keuangan pemerintah daerah tahun anggaran 2014 yang telah diaudit oleh Badan Pemeriksa Keuangan (BPK).Variabel independen berupa opini audit pemerintah daerah diperoleh melalui Badan Pemeriksa Keuangan (BPK). Realisasi belanja daerah dan pendapatan per kapita diperoleh melalui Badan Pusat Statistik (BPS).

Populasi, Sampel, dan Teknik Pengambilan Sampel

Populasi dalam penelitian ini adalah pemerintah kota dan pemerintah kabupaten di Pulau Jawa sebanyak 113 pemerintah daerah. Pulau Jawa dipilih sebagai populasi dalam penelitian ini karena Pulau Jawa merupakan pusat dari segala aktivitas negeri mulai dari pemerintahan, ekonomi, pendidikan dan urbanisasi (Malinda, 2016). Pengambilan sampel menggunakan teknik sampel bertujuan (purposive sampling), yaitu teknik pengambilan sampel yang didasarkan pada kriteriakriteria tertentu (Sekaran dan Bougi, 2016). Kriteria yang ditetapkan dalam pengambilan sampel yaitu pemerintah kabupaten/kota di Pulau Jawa, mempunyai website resmi yang dapat diakses, dan tersedianya laporan keuangan pemerintah daerah tahun anggaran 2014.

Variabel Penelitian dan Definisi Operasional

Publikasi Laporan Keuangan di Internet Oleh Pemerintah Daerah

Publikasi laporan keuangan di internet dinilai dari ada tidaknya Laporan Keuangan Pemerintah Daerah (LKPD) pada website resmi pemerintah daerah. Pengukuran variabel dependen ini sesuai dengan penelitian (Laswad dkk., 2005), yaitu menggunakan variabel dummy untuk mengukur penungkapan laporan keuangan di internet.Pemerintah daerah yang memublikasikan laporan keuangannya diwebsite resminya diberi skor 1, sedangkan pemerintah daerah yang memiliki website resmi namun tidak digunakan sebagai media untuk memublikasikan laporan keuangan diberi skor 0 .

Opini audit

Opini audit merupakan refleksi dari kualitas laporan keuangan. Opini audit secara bertingkat terdiri dari: Tidak Wajar (TW), Tidak Memberikan Pendapat (TMP), Wajar Dengan Pengecualian (WDP), Wajar Tanpa Pengecualian Dengan Paragraf Penjelasan (WTP DPP), dan Wajar Tanpa Pengecualian (WTP). Variabel ini diukur dengan menggunakan variabel dummy yaitu jika pemerintah daerah menerima opini WTP maka diberi nilai 1 sedangkan pemerintah daerah yang menerima opini selain WTP diberi nilai 0 .

\section{Belanja Daerah}

Belanja daerah adalah semua kewajiban daerah yang diakui sebagai pengurang nilai kekayaan bersih dalam periode tahun anggaran yang bersangkutan. Variabel belanja daerah diukur melalui realisasi belanja langsung dan belanja tidak langsung yang dikeluarkan oleh pemerintah daerah. Data realisasi belanja daerah dalam bentuk ratusan juta rupiah sehingga data tersebut di logaritma. Adapun rumus realisasi belanja daerah sebagai berikut:

Belanja Daeraht $=$ Realisasi Belanja Langsungt + Realisasi Belanja Tidak Langsungt 


\section{Pendapatan Per Kapita}

Pendapatan per kapita yang digunakan dalam penelitian ini yaitu Produk Domestik Regional Bruto (PDRB) per kapita. Produk Domestik Regional Bruto (PDRB) adalah jumlah nilai produk barang dan jasa akhir yang dihasilkan oleh seluruh unit produksi di dalam suatu wilayah atau daerah pada suatu periode tertentu, biasanya dalam periode satu tahun. PDRB per kapita diperoleh dari pembagian PDRB atas dasar harga berlaku dengan jumlah penduduk di dalam suatu wilayah. Jumlah penduduk yang digunakan untuk membagi adalah jumlah penduduk pada pertengahan tahun. Adapun rumus pendapatan per kapita sebagai berikut:

$$
\text { PDRB Per Kapita }=\frac{\text { PDRB }_{\mathrm{t}}}{\text { Jumlah Penduduk }_{\mathrm{t}}}
$$

Keberadaan Situs LPSE

Sistem Layanan Pengadaan Secara Elektronik (LPSE) adalah sistem pengadaan barang dan jasa pemerintah yang dilaksanakan secara elektronik dengan cara memanfaatkan dukungan teknologi informasi yang bertujuan untuk meningkatkan dan menjamin terjadinya efisiensi, efektifitas, transparansi, dan akuntabilitas dalam pembelanjaan uang negara. Variabel ini diukur dengan menggunakan variabel dummy yaitu jika pemerintah daerah mempunyai situs LPSE yang online maka diberi nilai 1 sedangkan pemerintah daerah yang tidak mempunyai situs LPSE atau mempunyai situs LPSE tetapi offline maka diberi nilai 0 .

\section{Analisis Regresi Logistik}

Teknik analisis data dalam penelitian ini menggunakan analisis regresi logistik. Analisis regresi logistik digunakan jika asumsi multivariate normal distribution tidak terpenuhi karena variabel independen merupakan campuran antara variabel kontinyu (metrik) dan kategorial (nonmetrik) (Jogiyanto, 2013). Selain itu, analisis regresi logistik dipilih karena variabel dependen dalam penelitian ini adalah kategorikal atau dikotomi (nominal), yaitu pemerintah daerah yang melakukan publikasi laporan keuangan di internet dilambangkan dengan angka 1 dan pemerintah daerah yang tidak melakukan publikasi laporan keuangan di internet dilambangkan dengan angka 0. Persamaan regresi logistik sebagai berikut:

$$
\operatorname{Ln} \frac{\mathrm{P}}{1-\mathrm{p}}=\beta_{0}+\beta_{1}(\text { OPDIT })+\beta_{2}(\text { BELANJA })+\beta_{3}(\text { PENDPK })+\beta_{4}(\text { LPSE })+\mathrm{e}
$$

Keterangan:

$\begin{array}{ll}\operatorname{Ln} \frac{\mathrm{P}}{1-\mathrm{p}} & =\text { Publikasi laporan keuangan pemerintah daerah di internet } \\ \text { OPDIT } & =\text { Opini audit } \\ \text { BELANJA } & =\text { Belanja daerah } \\ \text { PENDPK } & =\text { Pendapatan per kapita } \\ \text { LPSE } & =\text { Keberadaan situs LPSE } \\ \mathrm{e} & =\text { Residual }\end{array}$

\section{HASIL DAN PEMBAHASAN}

Gambaran Umum Penelitian

Penelitian ini merupakan penelitian kuantitatif dengan menggunakan data sekunder. Data sekunder diperoleh melalui observasi setiap situs resmi pemerintah daerah di Pulau Jawa. Populasi 
dalam penelitian ini adalah seluruh pemerintah daerah kabupaten / kota yang ada di Pulau Jawa kecuali kabupaten/kota di Provinsi DKI Jakarta yaitu sejumlah 113 pemerintah daerah kabupaten/kota. Sampel diambil dengan teknik purposive sampling. Berdasarkan penentuan jumlah sampel, diperoleh sampel penelitian sejumlah 108 sampel. Sampel tersebut diperoleh dari hasil observasi yang dilakukan pada masing-masing website resmi pemerintah daerah kabupaten/kota yang ada di Pulau Jawa.

Analisis Data dan Pembahasan

\section{Statistik Deskriptif}

Variabel opini audit (OPDIT) diukur dengan menggunakan variabel dummy. Nilai minimum variabel yaitu 0 untuk opini audit laporan keuangan Non WTP (WDP, TW, TMP) dan nilai maksimumnya yaitu 1 untuk opini audit laporan keuangan pemerintahannya adalah WTP. Pada penelitian ini di peroleh hasil bahwadi Pulau Jawa, rata-rata opini audit laporan keuangan pemerintah kabupaten/kota di Pulau Jawa adalah 0,51. Hal tersebut menunjukkan bahwa sebagian besar pemerintah kabupaten/kota di Pulau Jawa mendapatkan opini WTP yaitu sebanyak 51\% pemerintah daerah kabupaten/kota.

Variabel belanja daerah (BELANJA) memiliki nilai minimum sebesar 20,07 atau Rp. 517.938.317 (Kabupaten Pangandaran) dan nilai maksimum sebesar 22,68 atau Rp. 7.049.525.544 (Kota Surabaya). Rata-rata belanja daerah kabupaten/kota di Pulau Jawa yang diukur dari realisasi belanja langsung dan belanja tidak langsung sebesar 21,2227 atau Rp. 1.873.128.332. Nilai rata-rata sebesar 21,2227 lebih mendekati nilai maksimum, sehingga hal tersebut menunjukkan bahwa realisasi belanja daerah kabupaten/kota di Pulau Jawa dapat dikatakan maksimum atau tinggi.

Variabel pendapatan per kapita (PENPK) memiliki nilai minimum sebesar 12,94 (Kabupaten Cianjur) dan nilai maksimum sebesar 315,40 (Kota Kediri). Rata-rata pendapatan per kapita pemerintah kabupaten/kota di Pulau Jawa adalah 34,2064. Nilai rata-rata sebesar 34,2064 lebih mendekati nilai minimum, sehingga hal tersebut menunjukkan bahwa pendapatan per kapita pemerintah kabupaten/kota di Pulau Jawa dapat dikatakan tinggi.

Variabel keberadaan situs LPSE (LPSE) diukur dengan menggunakan variabel dummy. Nilai minimum variabel LPSE adalah 0 yang berarti bahwa situs LPSE pemerintah kabupaten/kota berstatus offline atau errror dan nilai maksimum sebesar 1 yang berarti bahwa situs LPSE yang dimiliki oleh pemerintah kabupaten/kota online. Rata-rata variabel keberadaan situs LPSE adalah 0,9074. Nilai rata-rata sebesar 0,9074 lebih mendekati nilai maksimum, sehingga hal tersebut menunjukkan bahwa keberadaan situs LPSE kabupaten/kota di Pulau Jawa berstatus online.

\section{Uji Asumsi Klasik (Multikolonieritas)}

Uji Asumsi Klasik dengan uji multikolonieritas bertujuan untuk menguji apakah dalam model regresi yang terbentuk ada korelasi yang tinggi atau sempurna di antara variable bebas atau tidak. Jika dalam model regresi yang terbentuk terdapat korelasi yang tinggi atau sempurna di antara variabel bebas maka model regresi tersebut dinyatakan mengandung gejala multikolonieritas. Tidak adanya multikolonieritas ditunjukkan dengan nilai tolerance $>0.10$ dan nilai VIF $<10$ (Suliyanto, 2011).

Uji Nilai Hosmer and Lemeshow's Goodness of Fit

Nilai statistik Hosmer and Lemeshow's Goodness of fit sebesar 3,875 dengan $8 \mathrm{df}$ dan probabilitas signifikansi sebesar 0,868 . Nilai probabilitas siginifikansi lebih besar dari $\alpha=5 \%$ atau 0,05 , maka $\mathrm{H} 0$ diterima dan berarti model mampu memprediksi nilai observasinya atau dapat dikatakan model dapat diterima. Dengan demikian disimpulkan bahwa model regresi logistik yang digunakan dapam peneitian ini dapat menggambarkan hubungan antara opini audit, belanja daerah, 
pendapatan per kapita, dan keberadaan situs LPSE dengan publikasi laporan keuangan pemerintah daerah di internet.

Uji Nilai -2 Log Likelihood

Uji -2 Log Likelihoodpada menunjukkan nilai -2 Log Likelihood pada awal (Blok Number =0) sebesar 149,386 dan -2 Log Likelihood pada akhir (Blok Number =1) sebesar 115,713. Dengan demikian terjadi penurunan angka -2 Log Likelihood sebesar 33,673 yang menunjukkan model regresi baik atau fit.

Uji Koefisien Determinasi (Nagelkerke’s R Square)

Nilai Cox Snell'R Square sebesar 0,268 dan nilai Nagelkerke's R Square adalah 0,358 atau $36 \%$. Hal ini menunjukkan bahwa variabel-variabel independen dalam penelitian ini dapat menjelaskan variabel publikasi laporan keuangan pemerintah daerah sebesar 36\% sedangkan sisanya $64 \%$ dapat dijelaskan oleh faktor-faktor lain diluar model penelitian ini.

Pengujian Hipotesis

Hasil uji hipotesis dengan menggunakan regresi logistik adalah seperti yang ada pada tabel 2 berikut ini:

Tabel 2 Hasil Uji Regresi Logistik

\begin{tabular}{llcccccc}
\hline & & B & \multicolumn{1}{c}{ S.E } & Wald & df & Sig. & Exp (B) \\
\hline \multirow{3}{*}{ Step 1 ${ }^{a}{ }^{a}$} & OPDIT &, 391 &, 455 &, 738 & 1 &, 390 & 1,478 \\
& BELANJA & 2,108 &, 637 & 10,956 & 1 &, 001 & 8,230 \\
& PENPK &, 043 &, 016 & 6,777 & 1 &, 009 & 1,043 \\
& LPSE &, 361 &, 781 &, 213 & 1 &, 644 & 1,434 \\
& Constant & $-46,625$ & 13,629 & 11,703 & 1 &, 001 &, 000 \\
\hline
\end{tabular}

Keterangan: OPDIT = opini audit; BELANJA = Belanja Daerah; PENPK = Pendapatan per kapita; LPSE $=$ Keberadaan situs LPSE

Berdasarkan informasi pada tabel 2 diperoleh persamaan sebagai berikut:

$$
\operatorname{Ln} \frac{\text { PUB }}{1-\text { PUB }}=-46,625+0,3910 \text { PDIT }+2,108 \text { BELANJA }+0,043 \text { PENPK }+0,361 \mathrm{LPSE}+\mathrm{E}
$$

Konstanta $\operatorname{Exp}(\mathrm{B})=0,000$, artinya jika opini audit, belanja daerah, pendapatan per kapita, dan keberadaan situs LPSE nilainya tetap, maka probabilitas publikasi laporan keuangan pemerintah daerah di internet tidak mengalami perubahan.

Koefisien $\beta 1=0,391$ (positif) dan $\operatorname{Exp}(\beta) 1=1,478$, artinya pemerintah daerah yang mendapatkan opini WTP mempunyai probabilitas untuk melakukan publikasi laporan keuangan di internet sebesar 1,478 kali dibandingkan pemerintah daerah yang mendapatkan opini selain WTP. Oleh karena nilai $\beta 1$ bernilai positif, maka opini audit mempunyai hubungan positif terhadap publikasi laporan keuangan pemerintah daerah di internet. Variabel opini audit (OPDIT) memiliki nilai signifikansi sebesar 0,195. Nilai tersebut lebih besar dari tingkat alpha yang ditentukan yaitu 5\% atau 0,05 sehingga dapat diinterpretasikan bahwa variabel opini audit (OPDIT) tidak memiliki pengaruh signifikan terhadap publikasi laporan keuangan pemerintah daerah di internet. Oleh karena itu, hipotesis pertama (H1) dalam penelitian ini ditolak.

Koefisien $\beta 2=2,108$ (positif) dan $\operatorname{Exp}(\beta) 2=8,230$, artinya semakin tinggi realisasi belanja daerah, maka probabilitas pemerintah daerah untuk melakukan publikasi laporan keuangan di internet akan meningkat sebesar 8,230 kali. Oleh karena nilai $\beta 2$ bernilai positif, maka realisasi belanja daerah mempunyai hubungan positif terhadap publikasi laporan keuangan pemerintah 
daerah di internet. Variabel belanja daerah (BELANJA) memiliki nilai signifikansi sebesar 0,001. Nilai tersebut lebih kecil dari tingkat alpha yang ditentukan yaitu $5 \%$ atau 0,05 sehingga dapat diinterpretasikan bahwa variabel belanja daerah (BELANJA) memiliki pengaruh signifikan terhadap publikasi laporan keuangan pemerintah daerah di internet. Oleh karena itu, hipotesis kedua (H2) dalam penelitian ini diterima.

Koefisien $\beta 3=0,043$ (positif) dan $\operatorname{Exp}(B) 3=1,043$, artinya semakin tinggi pendapatan per kapita, maka probabilitas pemerintah daerah untuk melakukan publikasi laporan keuangan di internet akan meningkat sebesar 1,043 kali. Oleh karena nilai $\beta 3$ bernilai positif, maka pendapatan per kapita mempunyai hubungan positif terhadap publikasi laporan keuangan pemerintah daerah di internet. Variabel pendapatan per kapita (PENPK) memiliki nilai signifikansi sebesar 0,005. Nilai tersebut lebih kecil dari tingkat alpha yang ditentukan yaitu 5\% atau 0,05 sehingga dapat diinterpretasikan bahwa variabel pendapatan per kapita (PENPK) memiliki pengaruh signifikan terhadap publikasi laporan keuangan pemerintah daerah di internet. Oleh karena itu, hipotesis ketiga (H3) dalam penelitian ini diterima.

Koefisien $\beta 4=0,361$ (positif) $\operatorname{Exp}(\beta) 4=1,434$, artinya pemerintah daerah yang situs LPSE berstatus online mempunyai probabilitas untuk melakukan publikasi laporan keuangan di internet sebesar 1,434 kali dibandingkan pemerintah daerah yang situs LPSE berstatus offline. Oleh karena nilai $\beta 4$ bernilai positif, maka keberadaan situs LPSE mempunyai hubungan positif terhadap publikasi laporan keuangan pemerintah daerah di internet. Variabel keberadaan situs LPSE (LPSE) memiliki nilai signifikansi sebesar 0,322. Nilai tersebut lebih besar dari tingkat alpha yang ditentukan yaitu5\% atau 0,05 sehingga dapat diinterpretasikan bahwa variabel keberadaan situs LPSE (LPSE) tidak memiliki pengaruh signifikan terhadap publikasi laporan keuangan pemerintah daerah di internet. Oleh karena itu, hipotesis keempat (H4) dalam penelitian ini ditolak.

Pembahasan

Pengujian hipotesis 1 tidak dapat membuktikan adanya pengaruh opini audit terhadap publikasi laporan keuangan pemerintah daerah di internet. Hasil tersebut bertentangan dengan penelitian Rahim dan Dwi (2016) yang menunjukkan bahwa opini audit memiliki hubungan positif terhadap pengungkapan informasi keuangan pada website. Hasil penelitian ini menunjukkan bahwa tidak adanya pengaruh opini audit terhadap publikasi laporan keuangan pemerintah daerah di internet, dimana hasil tersebut sejalan dengan penelitian Trisnawati dan Komarudin (2014).

Teori sinyal menjelaskan bagaimana pemerintah memberikan sinyal kepada masyarakat atas amanah yang telah diberikan masyarakat kepada pemerintah. Opini audit yang diperoleh pemerintah daerah dapat dijadikan sebagai sinyal kepada masyarakat. Semakin baik opini audit yang diperoleh pemerintah daerah, seharusnya semakin mendorong pemerintah daerah untuk memberikan sinyal kepada masyarakat bahwa kinerja pemerintah daerah baik melalui publikasi laporan keuangan. Akan tetapi, hasil penelitian ini berbeda. Penelitian ini menunjukkan bahwa opini audit WTP tidak mendorong pemerintah daerah untuk melakukan publikasi laporan keuangan di internet.

Opini WTP menunjukkan bahwa pemerintah daerah telah menyelenggarakan laporan keuangan sesuai dengan Standar Akuntansi Pemerintah (SAP) dan memiliki Sistem Pengendalian Intern Pemerintah (SPIP) yang baik. Opini WTP menjadi dambaan bagi setiap pemerintah pusat maupun daerah. Oleh karena itu, sesuai dengan teori sinyal seharusnya semakin baik opini audit pemerintah daerah akan mendorong pemerintah daerah melakukan publikasi laporan keuangannya di internet.

Menurut Nadjib (2012) untuk mencapai opini WTP, beberapa kepala daerah melakukan suap kepada tim BPK agar daerah mereka mendapatkan opini WTP. Terungkapnya kasus suap kepada auditor BPK perwakilan Jawa Barat demi mendapatkan opini WTP merubah persepsi masyarakat terhadap kualitas opini WTP. Opini WTP tidak dapat memberikan jaminan bahwa pemerintah daerah bebas dari korupsi. Sehingga, opini WTP tidak lagi menunjukkan sinyal pengelolaan keuangan pemerintah yang baik. Persepsi masyarakat yang mulai berubah membuat opini audit secara tidak langsung memengaruhi pemerintah daerah dalam memublikasikan laporan 
keuangannya (Trisnawati dan Komarudin, 2014). Oleh karena itu, opini WTP yang diperoleh pemerintah daerah tidak mendorong pemerintah daerah untuk melakukan publikasi laporan keuangan di internet.

Disisi lain, sinyal yang ingin diberikan oleh pemerintah daerah kepada masyarakat bukan melalui opini audit melainkan melalui pembangunan infrastruktur. Pemerintah daerah lebih berfokus pada pembenahan dan pembangunan infrastruktur. Sehingga, pembangunan infrastruktur tersebut dijadikan sebagai sinyal kepada masyarakat. Oleh karena itu, opini audit tidak dijadikan sebagai sinyal kepada masyarakat dan tidak mendorong pemerintah daerah untuk melakukan publikasi laporan keuangannya di internet.

Pengujian hipotesis 2 mengenai pengaruh belanja daerah terhadap publikasi laporan keuangan pemerintah daerah menunjukkan bahwa terdapat pengaruh signifikan terhadap publikasi laporan keuangan pemerintah daerah di internet. Hasil penelitian ini mendukung penelitian dari Pratama dkk. (2015) serta Hendriyani dan Afrizal (2015) yang menunjukkan bahwa belanja daerah memiliki pengaruh positif terhadap publikasi konten informasi pelaporan keuangan pemerintah daerah di internet.

Semakin tinggi belanja daerah, maka mendorong pemerintah daerah untuk lebih terbuka terhadap informasi keuangan pada websitenya. Hal ini sesuai dengan teori sinyal. Realisasi belanja daerah dijadikan sebagai suatu sinyal oleh pemrintah daerah kepada masyarakat bahwa pemerintah daerah telah memberikan pelayanan yang maksimum kepada masyarakat. Sehingga, realisasi belanja daerah mendorong pemerintah untuk melakukan publikasi laporan keuangannya di internet.

Pada dasarnya, belanja daerah digunakan untuk meningkatkan pelayanan terhadap masyarakat. Dana yang digunakan untuk meningkatkan pelayanan juga bersumber dari masyarakat. Oleh sebab itu, pemerintah daerah memiliki kewajiban untuk meningkatkan transparansinya sebagai bentuk pertanggungjawaban terhadap masyarakat akan dana yang dikeluarkan untuk belanja daerah.

Realisasi belanja daerah yang tinggi akan mendorong pemerintah daerah untuk memublikasikan laporan keuangannya di internet. Hal tersebut untuk menunjukkan kepada masyarakat seberapa besar dana yang dianggarkan melalui APBD telah digunakan oleh pemerintah daerah untuk memberikan pelayanan kepada masyarakat. Sehingga semakin besar pelayanan yang diberikan kepada masyarakat, semakin besar pula keinginan pemerintah daerah untuk memublikasikan laporan keuangan di internet.

Pengujian hipotesis 3 mengenai pengaruh pendapatan per kapita terhadap publikasi laporan keuangan pemerintah daerah di internet menunjukkan bahwa pendapatan per kapita memiliki pengaruh signifikan terhadap publikasi laporan keuangan pemerintah daerah di internet. Hasil penelitian tersebut sesuai dengan peneltian Hudoyo dan Amir (2014) yang menunjukkan bahwa pendapatan per kapita yang diperoleh suatu daerah berpengaruh terhadap pelaporan keuangan di internet oleh pemerintah daerah.

Pendapatan per kapita merupakan indikator dari kesejahteraan masyarakat. Jika tingkat kesejahteraan suatu daerah baik, maka pola pikir masyarakat juga cenderung lebih maju, serta semakin tinggi pula political monitoring yang dilakukan masyarakat kepada pemerintah. Masyarakat akan menuntut pemerintah daerah untuk lebih transparansi dalam melakukan pengolalaan keuangan daerah.

Semakin besar pendapatan per kapita yang diperoleh suatu daerah akan mendorong pemerintah daerah untuk memublikasikan laporan keuangannya di internet. Hasil penelitian ini sesuai dengan teori sinyal. Pendapatan per kapita dijadikan sebagai sinyal kepada masyarakat atas keberhasilan pemerintah daerah. Pemerintah daerah yang mampu meningkatkan pendapatan per kapita, maka pemerintah tersebut mampu mensejahterakan masyarakatnya. Sehingga pemerintah daerah akan melakukan publikasi laporan keuagannya di internet untuk menunjukkan kepada masyarakat bahwa pemerintah daerah telah berhasil mensejahterakan masyarakat.

Pengujian hipotesis 4 tidak dapat membuktikan adanya pengaruh keberadaan situs LPSE terhadap publikasi laporan keuangan pemerintah daerah di internet. Variabel keberadaan situs LPSE belum pernah dilakukan oleh peneliti sebelumnya. Hasil penelitian ini menunjukkan bahwa 
keberadaan situs LPSE tidak memiliki pengaruh terhadap publikasi laporan keuangan pemerintah daerah di internet.

LPSE merupakan suatu unit yang memfasilitasi pengadaan barang/jasa yang dilaksanakan secara elektronik. Keberadaan situs LPSE yang ada di pemerintah kab/kota di Pulau Jawa sebesar $90 \%$ berstatus online dan sisanya sebesar $10 \%$ masih offline atau dalam perbaikan. Pengadaan barang/jasa yang dilakukan secara elektronik akan lebih meningkatkan transparansi dan akuntabilitas dalam menggunakan uang negara. Sehingga, keberadaan situs LPSE dapat dijadikan sebagai sinyal kepada masyarakat bahwa pemerintah daerah transparan dalam menggunakan uang negara. Sehingga akan mendorong pemerintah daerah untuk melakukan publikasi laporan keuangan pemerintah daerah di internet.

Akan tetapi, hasil penelitian ini berbeda dengan teori sinyal. Keberadaan situs LPSE tidak mendorong pemerintah daerah memublikasikan laporan keuangannya di internet. Peningkatan tranparansi dan akuntabilitas pengadaan barang/jasa tidak dibarengi dengan peningkatan transparansi laporan keuangan pemerintah daerah. Pengadaan barang/jasa yang dilakukan secara elektronik tidak mendorong pemerintah daerah untuk meningkatkan transparansi dan akuntabilitas laporan keuangan dengan cara memublikasikan laporan keuangan di internet.

Adanya perbedaan kepentingan antara situs LPSE dan laporan keuangan menjadi faktor yang menyebabkan keberadaan situs LPSE tidak mendorong transparansi laporan keuangan di website. Keberadaan situs LPSE tersebut hanya untuk mendukung transaksi pengadaan barang/jasa yang dimana terpisah dari laporan keuangan pemerintah daerah. Oleh karena itu, keberadaan situs LPSE tidak mendorong pemerintah daerah memublikasikan laporan keuangannya di internet.

\section{KESIMPULAN}

Berdasarkan hasil penelitian mengenai analisis faktor yang berpengaruh terhadap publikasi laporan keuangan di internet yang terdiri dari lima variabel yaitu opini audit, belanja daerah, pendapatan per kapita, dan keberadaan situs LPSE dapat disimpulkan bahwa opini audit dan keberadaan situs LPSE tidak memiliki pengaruh terhadap publikasi laporan keuangan di internet. Sedangkan belanja daerah dan pendapatan per kapita berpengaruh terhadap publikasi laporan keuangan pemerintah daerah di internet.

Hasil pengujian secara empiris membuktikan bahwa realisasi belanja daerah memiliki pengaruh terhadap publikasi laporan keuangan pemerintah daerah di internet. Dengan demikian, pemerintah daerah hendaknya menggunakan belanja daerah secara maksimal untuk memberikan pelayanan kepada masyarakat serta memublikasikan laporan keuangannya di internet sebagai bentuk transparansi dan pertanggungjawaban atas pengelolaan keuangan daerah.

Hasil pengujian secara empiris membuktikan bahwa pendapatan per kapita memiliki pengaruh terhadap publikasi laporan keuangan pemerintah daerah di internet. Dengan demikian, pemerintah daerah hendaknya meningkatkan pendapatan per kapita untuk mensejahterakan masyarakat serta memublikasikan laporan keuangannya di internet sebagai sinyal keberhasilan pemerintah daerah.

Berdasarkan hasil penelitian, saran untuk penelitian selanjutnya yaitu pertama menambahkan variabel lain yang diduga berpengaruh terhadap publikasi laporan keuangan di internet seperti kompetisi politik masing- masing daerah, tingkat investasi, temuan audit, kualitas

informasi yang diungkapkan dalam website dan press visibility yang sering digunakan sebagai indikator oleh negara lain dalam menilai publikasi laporan keuangan pada website. Kedua, penelitian selanjutnya dapat menggunakan periode yang lebih panjang sehingga lebih baik untuk menggambarkan publikasi laporan keuangan pemerintah daerah. Ketiga, penelitian selanjutnya sebaiknya membagi menjadi 2 kategori yaitu kategori pemerintah daerah di Pulau Jawa dan pemerintah daerah di luar Pulau Jawa. Alasannya karena adanya perbedaan sosial, ekonomi, dan budaya antara di Pulau Jawa dan di luar pulau Jawa yang diduga juga akan memiliki pengaruh yang berbeda terhadap publikasi laporan keuangan. 


\section{LAMPIRAN}

Lampiran 1 Hasil Analisis Deskriptif

Descriptive Statistics

\begin{tabular}{llllll}
\hline & $\mathrm{N}$ & \multicolumn{1}{c}{ Minimum } & \multicolumn{1}{c}{ Maximum } & \multicolumn{1}{c}{ Mean } & \multicolumn{1}{c}{ Std. Deviation } \\
\hline OPDIT & 108 &, 00 & 1,00 &, 5093 &, 50224 \\
BELANJA & 108 & 20,07 & 22,68 & 21,2227 &, 48455 \\
& & 517.938 .317 & 7.049 .525 .544 & 1.873 .128 .332 & \\
PENPK & 108 & 12,94 & 315,40 & 34,2064 & 34,82675 \\
LPSE & 108 &, 00 & 1,00 &, 9074 &, 29121 \\
Valid N & 108 & & & & \\
(Listwise) & & & & & \\
\hline
\end{tabular}

Lampiran 2 Hasil Uji Multikolinearitas

Coefficients $^{a}$

\begin{tabular}{|c|c|c|c|c|c|c|c|c|}
\hline & \multirow{2}{*}{ Model } & \multicolumn{2}{|c|}{$\begin{array}{l}\text { Unstandardized } \\
\text { Coefficients }\end{array}$} & \multirow{2}{*}{$\begin{array}{c}\text { Standardized } \\
\text { Coefficients } \\
\text { Beta }\end{array}$} & \multirow[t]{2}{*}{$\mathrm{t}$} & \multirow[t]{2}{*}{ Sig. } & \multicolumn{2}{|c|}{ Collinearity Statistics } \\
\hline & & B & $\begin{array}{l}\text { Std. } \\
\text { Error }\end{array}$ & & & & Tolerance & VIF \\
\hline \multirow{5}{*}{1} & (Constant) & $-7,686$ & 1,905 & & $-4,034$ & , 000 & & \\
\hline & OPDIT & ,089 & ,088 & ,090 & 1,020 & 310 & ,965 & 1,036 \\
\hline & BELANJA & 373 & ,090 & 361 & 4,141 & ,000 & ,981 & 1,019 \\
\hline & PENPK & ,003 & 001 & 237 & 2,663 & 009 & ,941 & 1,063 \\
\hline & LPSE & ,084 & ,150 & 049 & ,562 & ,575 & ,978 & 1,022 \\
\hline
\end{tabular}

Lampiran 3 Hasil Analisis Regresi Logistik

Case Processing Summary

\begin{tabular}{|c|c|c|c|}
\hline \multicolumn{2}{|c|}{ Unweighted Cases $^{n}$} & $\mathrm{~N}$ & Percent \\
\hline \multirow{3}{*}{ Selected Cases } & Included in Analysis & 108 & 100,0 \\
\hline & Missing Cases & 0 &, 0 \\
\hline & Total & 108 & 100,0 \\
\hline Unselected Cases & & 0 & ,0 \\
\hline Total & & 108 & 100,0 \\
\hline
\end{tabular}

a. If weight is in effect, see classification table for the total number of cases.

Dependent Variable Encoding

\begin{tabular}{cc}
\hline Original Value & Internal Value \\
\hline TIDAK PUBLIKASI & 0 \\
PUBLIKASI & 1 \\
\hline
\end{tabular}

Block 0: Beginning Block

Iteration History $y^{\text {abl, }}$

\begin{tabular}{lll}
\hline Iteration & -2 Log Likelihood & $\begin{array}{l}\text { Coefficient } \\
\text { Constant }\end{array}$ \\
\hline 1 & 149,386 &,- 111 \\
Step 0 & 149,386 &,- 111 \\
\hline
\end{tabular}

a. Constant is included in the model.

b. Initial -2 Log Likelihood: 149,386 
c. Estimation terminated at iteration number 2 because parameter estimates changed by less than , 001 .

Classification Table ${ }^{a, b}$

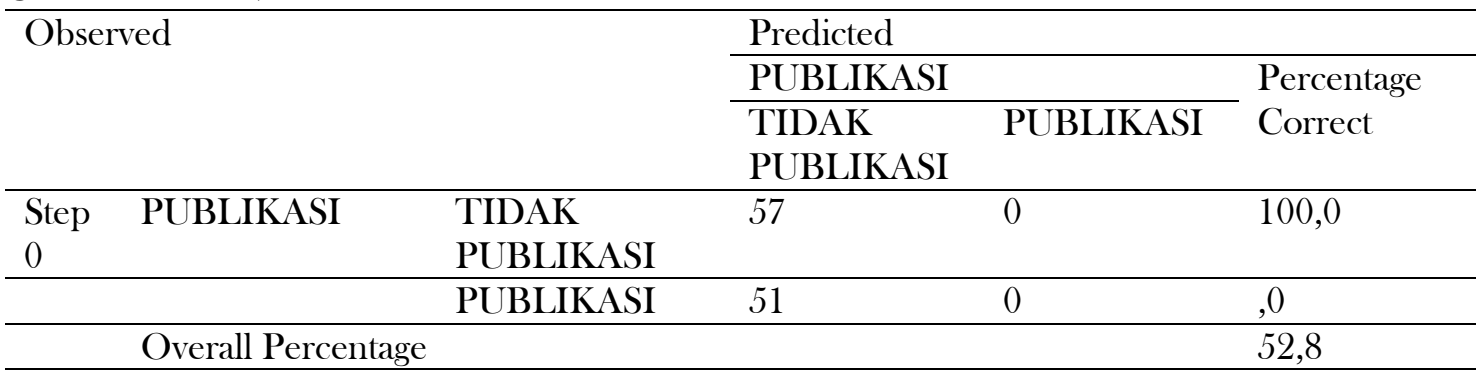

a. Constant is included in the model.

b. The cut value is, 500

Variables in the Equation

\begin{tabular}{|c|c|c|c|c|c|c|c|}
\hline & & B & S.E. & Wald & $\mathrm{df}$ & Sig. & $\operatorname{Exp}(B)$ \\
\hline Step 0 & Constant &,- 111 & ,193 & ,333 & 1 & 564 & ,895 \\
\hline
\end{tabular}

Variables not in the Equation

\begin{tabular}{|c|c|c|c|c|c|}
\hline & & & Score & $\mathrm{df}$ & Sig. \\
\hline & & OPDIT & 2,412 & 1 & , 120 \\
\hline \multirow[t]{4}{*}{ Step 0} & \multirow[t]{3}{*}{ Variables } & BELANJA & 17,046 & 1 & ,000 \\
\hline & & PENPK & 10,038 & 1 & ,002 \\
\hline & & LPSE & 1,312 & 1 & ,252 \\
\hline & \multicolumn{2}{|c|}{ Overall Statistics } & 25,290 & 4 & ,000 \\
\hline
\end{tabular}

Iteration History ab,c,d

\begin{tabular}{|c|c|c|c|c|c|c|c|}
\hline \multicolumn{2}{|c|}{ Iteration } & \multirow{2}{*}{$\begin{array}{cr}-2 & \text { Log } \\
& \text { Likelihood }\end{array}$} & \multicolumn{5}{|c|}{ Coefficients } \\
\hline \multicolumn{2}{|c|}{ meratuon } & & Constant & OPDIT & BELANJA & PENPK & LPSE \\
\hline \multirow{6}{*}{$\begin{array}{l}\text { Step } \\
1\end{array}$} & \multirow{6}{*}{$\begin{array}{l}1 \\
2 \\
3 \\
4 \\
5 \\
6\end{array}$} & 120,913 & $-32,745$ & ,358 & 1,493 &, 014 & 338 \\
\hline & & 116,587 & $-42,833$ & ,402 & 1,944 & ,029 & 395 \\
\hline & & 115,734 & $-45,779$ & ,389 & 2,070 & ,040 & ,361 \\
\hline & & 115,713 & $-46,599$ & ,391 & 2,107 & ,043 & ,360 \\
\hline & & 115,713 & $-46,625$ & ,391 & 2,108 & ,043 & ,361 \\
\hline & & 115,713 & $-46,625$ & ,391 & 2,108 & ,043 & ,361 \\
\hline
\end{tabular}

Model Summary

\begin{tabular}{|c|c|c|c|}
\hline Step & -2 Log likelihood & $\begin{array}{c}\text { Cox \& Snell R } \\
\text { Square }\end{array}$ & Nagelkerke R Square \\
\hline
\end{tabular}

\begin{tabular}{llll}
\hline 1 & $115,713^{\mathrm{a}}$ &, 268 &, 358 \\
\hline
\end{tabular}
a. Method: Enter
b. Constant is included in the model.
c. Initial -2 Log Likelihood: 149,386
d. Estimation terminated at iteration number 6 because parameter estimates changed by less than ,001. 
Omnibus Tests of Model Coefficients

\begin{tabular}{lllll}
\hline & & Chi-square & df & Sig. \\
\hline \multirow{3}{*}{ Step 1 1} & Step & 33,673 & 4 &, 000 \\
& Block & 33,673 & 4 &, 000 \\
& Model & 33,673 & 4 &, 000 \\
\hline
\end{tabular}

Hosmer and Lemeshow Test

\begin{tabular}{llll}
\hline Step & Chi-square & df & Sig \\
\hline 1 & 3,875 & 8 &, 868 \\
\hline
\end{tabular}

Contingency Table for Hosmer and Lemeshow Test

\section{PUBLIKASI = TIDAK}

PUBLIKASI

\begin{tabular}{|c|c|c|c|c|c|c|}
\hline & & Observed & Expected & Observed & Expected & \\
\hline \multirow{10}{*}{ Step 1} & 1 & 10 & 9,668 & 1 & 1,332 & 11 \\
\hline & $\overline{2}$ & 9 & 8,631 & 2 & 2,369 & 11 \\
\hline & 3 & 9 & 7,998 & 2 & 3,002 & 11 \\
\hline & 4 & 6 & 7,405 & 5 & 3,595 & 11 \\
\hline & 5 & 5 & 6,698 & 6 & 4,302 & 11 \\
\hline & 6 & 6 & 6,008 & 5 & 4,992 & 11 \\
\hline & 7 & 5 & 5,159 & 6 & 5,841 & 11 \\
\hline & 8 & 5 & 3,406 & 6 & 7,594 & 11 \\
\hline & 9 & 2 & 1,813 & 9 & 9,187 & 11 \\
\hline & 10 & 0 & ,213 & 9 & 8,787 & 9 \\
\hline
\end{tabular}

Classification Table

\begin{tabular}{|c|c|c|c|c|}
\hline \multirow[t]{4}{*}{ Observed } & & \multicolumn{3}{|l|}{ Predicted } \\
\hline & & PUBLIKASI & & Percentage \\
\hline & & TIDAK & PUBLIKASI & Correct \\
\hline & & \multicolumn{3}{|l|}{ PUBLIKASI } \\
\hline PUBLIKASI & TIDAK & 45 & 12 & 78,9 \\
\hline \multicolumn{5}{|c|}{ PUBLIKASI } \\
\hline & PUBLIKASI & 22 & 29 & 56,9 \\
\hline
\end{tabular}

a. The cut value is ,500

Variables in the Equation

\begin{tabular}{llllllll}
\hline & & B & S.E & Wald & df & Sig. & Exp (B) \\
\hline \multirow{3}{*}{ Step 1 $1^{a}$} & OPDIT &, 391 &, 455 &, 738 & 1 &, 390 & 1,478 \\
\cline { 2 - 8 } & BELANJA & 2,108 &, 637 & 10,956 & 1 &, 001 & 8,230 \\
\cline { 2 - 8 } & PENPK &, 043 &, 016 & 6,777 & 1 &, 009 & 1,043 \\
\cline { 2 - 8 } & LPSE &, 361 &, 781 &, 213 & 1 &, 644 & 1,434 \\
\cline { 2 - 8 } & Constant & $-46,625$ & 13,629 & 11,703 & 1 &, 001 &, 000 \\
\hline
\end{tabular}

a. Variable(s) entered on step 1: OPDIT, BELANJA, PENPK, LPSE.

Correlation Matrix

\begin{tabular}{lllllll}
\hline & & Constant & OPDIT & BELANJA & PENPK & LPSE \\
\hline \multirow{4}{*}{ Step 1} & Constant & 1,000 &,- 005 &,- 998 &,- 107 &,- 132 \\
\cline { 2 - 7 } & OPDIT &,- 005 & 1,000 &,- 006 &,- 082 &,- 071 \\
\cline { 2 - 7 } & BELANJA &,- 998 &,- 006 & 1,000 &, 084 &, 086 \\
\cline { 2 - 7 } & PENPK &,- 107 &,- 082 &, 084 & 1,000 &,- 121 \\
\cline { 2 - 7 } & LPSE &,- 132 &,- 071 &, 086 &,- 121 & 1,000 \\
\hline
\end{tabular}




\section{DAFTAR PUSTAKA}

Andriani, E. (2012). Pengaruh Opini Audit dan Temuan Audit terhadap Tingkat Pengungkapan pada Laporan Keuangan Pemerintah Daerah. Jurnal Akuntansi Fakultas Ekonomi Universitas Indonesia.

Asosiasi Penyelenggara Jasa Internet Indonesia (APJII). (2014). Profil Pengguna Internet Indonesia 2014. Jakarta: Asosiasi Penyelenggara Jasa Internet Indonesia.

Badan Pusat Statistik Indonesia. (2016). Statistik Keuangan Pemerintah Kabupaten/Kota 20142015. Jakarta.

Christina. (2013). Pengaruh Ukuran Pemerintah Daerah, Rasio Kemandirian Daerah, Rasio Pembiayaan Hutang, Belanja Daerah, Dan Tipe Pemerintahan Daerah terhadap Pelaporan Keuangan Pemerintah Daerah. Tesis Magister Akuntansi Universitas Sumatera Utara.

Handayani, S. (2010). Pengungkapan Laporan Keuangan Pemerintah Daerah Kabupaten/Kota di Indonesia Tahun 2006. Jurnal Ilmu Administrasi, VII (2).

Hendriyani, R \& Tahar, A. (2015). Analisis Faktor-Faktor Yang Memengaruhi Tingkat Pengungkapan Laporan Keuangan Pemerintah Provinsi Di Indonesia. Jurnal Bisnis dan Ekonomi Universitas Muhammadiyah Yogyakarta, 22 (1), 25-33.

Jama'an. (2008). Pengaruh Mekanisme Corporate Governance dan Kualitas Kantor Akuntan Publik terhadap Integritas Informasi Laporan Keuangan. Jurnal Universitas Diponegoro, Semarang.

Jogiyanto. (2013). Metodologi Penelitian Bisnis: Salah Kaprah dan Pengalaman-Pengalaman. Edisi 6. Penerbit: BPFE Yogyakarta

Khan, M. N. A. A. \& Ismail N. A. (2011). The level of internet financial reporting of Malaysian companies. Asian Journal of Accounting and Governance, 27-39.

Laswad, F., Fisher, R., \& Oyelere, P. (2005). Determinants of Voluntary Internet Financial Reporting by Local Government Authorities.

LKPP. (2011). Layanan Pengadaan Secara Elektronik (LPSE). Diakses dari: https://lpse.lkpp.go.id/eproc4/publik/tentangkami

LKPP. (2015). Petunjuk Penggunaan Aplikasi e-Purchasing Produk Barang/Jasa Pemerintah. Jakarta.

Malinda, G. (2016). Jelaskan Mengapa Pulau Jawa Padat Penduduknya. Diakses dari: http://gurupintar.com/threads/jelaskan-mengapa-pulau-jawa-padat penduduknya.856/

Nadjib, A. (2012. Fenomena Opini WTP. Diakses dari: http://nadjibsalatti.web.id/berita_detail/23/fenomena_opini_wtp

Peraturan Pemerintah Nomor 58 Tahun 2005 tentang Pengelolaan Keuangan Daerah. Peraturan Pemerintah No. 3 Tahun 2007 Pasal 27 tentang Laporan Penyelenggaraan Pemerintahan Daerah Kepada Pemerintah, Laporan Keterangan Pertanggungjawaban Kepala Daerah Kepada DPRD, dan Informasi Laporan Penyelenggaraan Pemerintahan Daerah Kepada Masyarakat.

Peraturan Menteri Dalam Negeri No. 7A Tahun 2007 Pasal 4 dan Pasal 5 tentang Tatacara Penyampaian Informasi dan Tanggapan atau Saran dari Masyarakat atas Laporan Penyelenggaraan Pemerintahan Daerah.

Peraturan Pemerintah No. 6 Tahun 2008 Pasal 53 tentang Pedoman Evaluasi Penyelenggaraan Pemerintahan Daerah.

Peraturan Pemerintah Nomor 71 tahun 2010 tentang Standar Akuntansi Pemerintahan. Peraturan Menteri Dalam Negeri Nomor 21 Tahun 2011. 
Pina, V. Torres, L. \& Royo S. (2010). Is E-Goverment Promoting Convergence Towards More Accountable Local Goverment? Internantional Public Management Journal, 13(4), 350380 .

Pratama, K. S. D., Desak N. S. W., \& Sudjana, E. (2015). Pengaruh Kompleksitas Pemerintah Daerah, Ukuran Pemerintah Daerah, Kekayaan Daerah, dan Belanja Daerah terhadap Pelaporan Keuangan Pemerintah Daerah. E-Jurnal Akuntansi Universitas Pendidikan Ganesha, Vol. 3(1).

Rahim, W., \& Martani, D. (2016). Analisis Pengaruh Tingkat Akses Internet, Kompetisi Politik, Opini Audit, Karakteristik Pemda, Dan Karakteristik Demografi Terhadap Pengungkapan Informasi Keuangan Dan Non-Keuangan Website Pemerintah Daerah. Simposium Nasional Akuntansi XIX Lampung, 24-27 Agustus 2016.

Rora, P. S. (2010). Pengaruh Kinerja, Tingkat Ketergantungan dan Karakteristik Pemda Terhadap Tingkat Pengungkapan Sukarela pada Situs Pemerintah Daerah Tahun 2010. Jurnal Akuntansi Fakultas Ekonomi Universitas Indonesia

Sekaran, U., \& Bougie, R. (2016). Research Methods for Business: A Skill Building Approach, John Wiley and sons, inc. London.

Styles, A. K. \& Tennyson, M. 2007. The Accessibility of Financial Reporting of US Municipalities on the Internet. Journal of Public Budgeting Accounting and FinancialManagement, 19 (1), 56-92.

Trisnawati, M. D. \& Komarudin, A. (2014). Determinan Publikasi Laporan Keuangan Pemerintah Daerah Melalui Internet. Simposium Nasional Akuntansi XVII Lampung, 2427 September 2014.

Undang-Undang Nomor 17 Tahun 2003 tentang Keuangan Negara.

UU Nomor 14 Tahun 2008tentang Keterbukaan Informasi Publik.

Undang-Undang Nomor 23 Tahun 2014 tentang Pemerintahan Daerah Pasal 1 Ayat 8.

UU Nomor 9 Tahun 2015 Perubahan Kedua atas UU Nomor 23 Tahun 2014.

Wolk, Harry I., Michael G. Tearney, dan James L Dodd. 2000. Accounting Theory: A Conceptual and Institutional Approach. South-Western CollegePublishing.

Wulandari, A. (2016). Faktor-Faktor yang Mempengaruhi Pengungkapan Belanja Bantuan Sosial pada Laporan Keuangan Pemerintah Daerah. Jurnal Fakultas Ekonomi Universitas Muhammadiyah Yogyakarta.

Wau, I \& Ratmono. 2015. Analisis Faktor-Faktor Yang Mempengaruhi Ketersediaan Dan Keteraksesan Internet Financial Reporting Oleh Pemerintah Daerah. Diponegoro Journal of Accounting, 4, (4), Halaman 1-12 http://ejournal-s1.undip.ac.id/index.php/accounting 